Jurnal Kejuruteraan 30(1) 2018: 39-46

https://doi.org/10.17576/jkukm-2018-30(1)

\title{
Flow Structure in Modern Cities: Wind Tunnel Investigation
}

\author{
(Struktur Arus dalam Kota Moden: Penyiasatan Terowong Angin) \\ Farhana Najwa Azman, Eslam Reda Lotfy, Ashraf Amer Abbas, Zambri Harun* \\ Department of Mechanical and Materials Engineering \\ Faculty of Engineering \& Built Environment, Universiti Kebangsaan Malaysia, Malaysia \\ Eslam Reda Lotfy \\ Mechanical Engineering Department, Alexandria University, 21544, Alexandria, Egypt
}

\begin{abstract}
Natural ventilation dominates the heat dissipation and pollutant dispersion in modern cities. Investigations into the flow structure and urban heat island in the Kuala Lumpur City Centre (KLCC) have been conducted by a few researchers. However, these studies were mainly accomplished by means of computational fluid dynamics. The critical problem with computational analysis is the lack of verification. As such, in this research, experimental tools such as the wind tunnel, hotwire anemometry, Pitot tube, and pressure and temperature sensors were utilized. The aim was to assess the ventilation performance of different city models with a height-to-width ratio that was similar to that of the KLCC. Several steps had to be performed before starting the study, among these being the building of the model. A $6 \times 6$ array of uniform acrylic blocks $(50 \times 50 \times 100 \mathrm{~mm})$ were arranged in line at equal distances. Three arrangements, representing different building densities $(35,25$ and $15 \%)$, were examined in the current research. The freestream wind speed was fixed at $5 \mathrm{~m} / \mathrm{s}$. The flow was found to be comprised of vortical structures, and attained an energetic turbulence in the downstream of the building areas as compared to the free flow areas. This study suggests keeping the plane area ratio in high-rise building cities within a $15-25 \%$ range. The study is beneficial to town planners as the construction of more skyscrapers is being planned.
\end{abstract}

Keywords: Wind flow; hotwire; urban environment, KLCC, turbulence intensity

ABSTRAK

Pengudaraan semulajadi merupakan komponen utama pelepasan haba dan penyerakan bahan pencemar di bandaraya moden. Kajian struktur aliran dan pulau haba di KLCC ini telah dijalankan oleh beberapa pengkaji sebelum ini namun ianya hanya tertumpu kepada simulasi dinamik bendalir komputeran. Dengan kajian simulasi, data yang diperoleh tidak dipastikan kesahihannya. Oleh hal yang demikian, kajian secara eksperimen seperti ini perlu dijalankan dengan menggunakan beberapa instrumen seperti terowong angin, anemometer dawai panas, tiub pitot-peranti tekanan dan peranti suhu. Kajian ini bertujuan untuk menilai prestasi pengudaraan untuk pelan-pelan perbandaran berlainan. Beberapa langkah perlu dilakukan sebelum memulakan kajian ini. Antaranya adalah membina blok blok akrilik dengan aturan $6 \times 6$ dan menyusun blok $(50 \times 50 \times 100 \mathrm{~mm})$ ini mengikut jarak yang berbeza untuk tiga model yang berlainan yang mencerminkan tiga kepadatan bangunan (35, 25 dan 15\%). Halaju ditetapkan pada $5 \mathrm{~m} / \mathrm{s}$. Hasil kajian menunjukkan aliran ini mengandungi struktur vorteks and mencapai perolakan bertenaga apabila aliran melepasi bangunan, jika dibandingkan dengan aliran bebas (tiada rintangan bangunan). Kajian ini mencadangkan agar nisbah bangunan - kawasan lapang dalam linkungan 15-25\% adalah sesuai. Kajian ini berguna kepada perancang bandar di mana banyak lagi bangunan pencakar langit yang masih lagi dalam perancangan.

Kata kunci: Model blok, anemometer dawai panas, halaju aliran angin, keamatan perolakan

\section{INTRODUCTION}

The urban heat island (UHI) phenomenon is the condition when a metropolitan area is significantly hotter than its rural surrounding due to entrapment of heat within the buildings and their surroundings. The UHI can be visualized as a hot air reservoir dome surrounding the urban area (Emmanuel 2005). The temperature differences will usually be greater at night than daylight and more noticeable when wind flow is very weak. Among the major causes are the changes that occur in the land surface resulting from urban development along with the waste heat produced from anthropogenic activities. In modern cities, the greenery is being replaced with solar absorbing materials such as asphalt and concrete for roads, buildings and other structures necessary to accommodate the growing population. This causes the surface temperature and ambient temperature to increase. Sailor (1994) argues that the low evaporative heat flux in urban areas, due to scarcity of green areas, intensifies the UHI effect. Moreover, the interior part of the city is exposed to weaker wind aerodynamics 
from those at the city countryside. High-rise buildings act as barriers and reduce the wind speed. Another negative effect imposed by the high-rise buildings is the absorption of more solar energy due to their complex geometries.

Few solutions have been proposed to minimize the energy consumption and hence the intensity of the UHI. According to Asimakopoulos et al. (2001), some of the factors that negatively affect consumers of low energy include the design and construction of urban buildings. Consequently, among the methods of reducing the UHI effect is to plan a suitable landscape. Regarding the ventilation in urban areas, the plan-area-ratio or building-packing-density (built area to total floor area) and the aspect ratios (building-height to street-width) are thought to be the most important parameters affecting the pedestrian wind (Razak et al. 2013). The building environment can be classified based on the flow structure to four categories (Hang et al. 2012), namely, (1) The isolated roughness flow regime (aspect ratio <0.3), (2) the wake interference flow regime (aspect ratio of 0.3-0.67), (3) the skimming flow regime (aspect ratio of 0.67-1.67) with one main vortex structure, and (4) the multi-vortex regime in deep (or high-rise) street canyons (aspect ratio $>$ 1.67). The third and fourth regimes are characterized with weak urban ventilation. Hang et al. (2011) numerically and experimentally investigated the wind flow through arrays of idealized high-rise buildings with aspect ratios from 2 to 5.3 and plane area density 0.25 or 0.4 . They delivered recommendations for planning high-rise building cities. They suggested constructing taller buildings to allow for wider streets without compromising the residential area. The built area should not extend beyond 1-2 km in length. Wide urban canyons such as gardens, parks etc. may be used to split large areas into multiple smaller ones. If taller building arrays become longer (than about $1 \sim 1.5 \mathrm{~km}$ ), the downstream buildings starve for fresh air (Hang and Li, 2010). Jiang et al. (2008) studied the velocity profiles in models of different building spacings, heights and layouts. They found the velocity profile for all models and the upstream profile converge at approximately $\mathrm{z} / \mathrm{H}=2.5$. Hang et al. (2012) assessed the net effects of mean flow to be more important for pollutant removal than turbulent diffusions. However, they predicted the turbulence diffusion to strengthen by lowering the aspect ratio or increasing stream wise street length. The dominant turbulence scales are of the order of the height of the buildings (Castro et al. 2006).

Liu et al. (2011) conducted CFD analysis for wind flow through 2D street canyons with a wide range of aspect ratios. They indicated the importance of turbulence in air change and pollutant removal. From their LES of wind flow through a modified Malaysian terraced house canyon, Razali et al. (2016) found that the modification can affect the wind flow where the canyon is narrow. A CFD analysis held by Zaki et al. (2016) substantiated the importance of small-scale roughness upwind and downwind of the buildings. These enhance turbulence on account of mainstream velocity. Salim et al. (2011) performed a wind tunnel study for a street canyon with a packed tree-crown. The tree-crown tested was of a height comparable to that of the street canyon. It

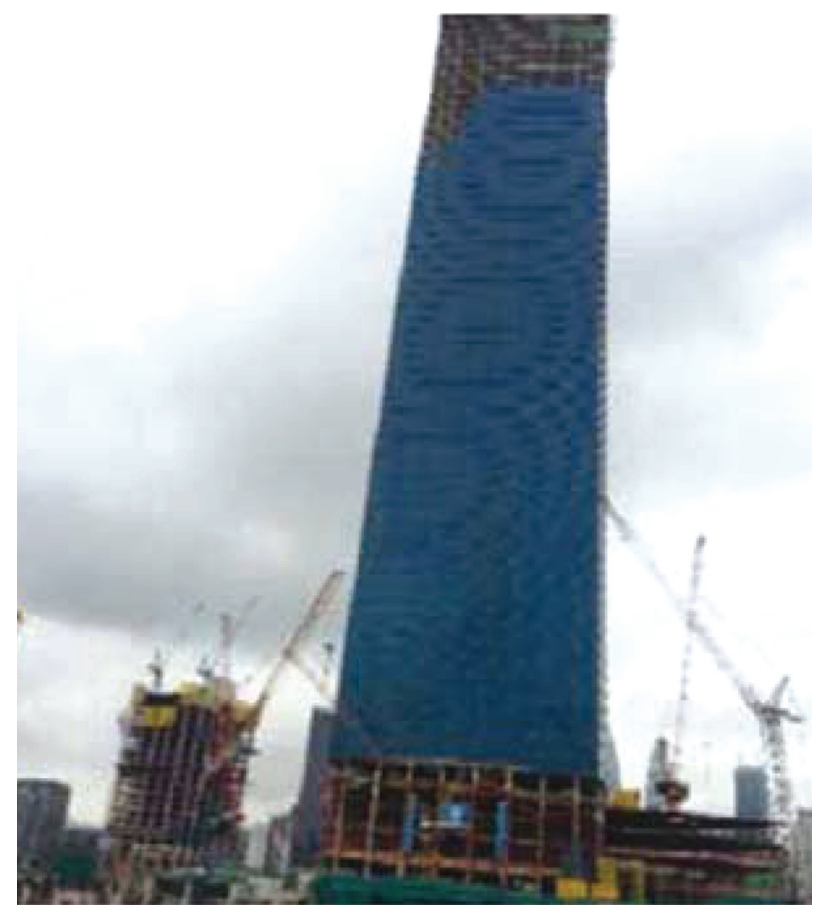

FIGURE 1. A photo of The Exchange 106 or previously known as TRX Signature Tower during construction taken on 2 November 2017 (KLCC at the back of this structure)

was found that the tree-crown dampens the circulation and hence increases the concentration of the pollutants within the street canyon. Gousseau et al. (2011) simulated the pollutant dispersion in downtown Montreal, Canada, using two different modeling approaches (RANS and LES). They validated the results by wind tunnel experiments using a $1 / 200$ scale model of the urban area. They found that the numerical simulation, including LES, can model the pollutant dispersion in urban areas with errors ranging between 0 and $100 \%$ depending on the location within the urban area and direction of the wind

Most studies have implemented the computational fluid dynamic (CFD) simulations, especially the large eddy simulation (LES) technique, to investigate the flow structure, heat dissipation and pollutant dispersion in the Kuala Lumpur City Center (KLCC) (Harun and Reda 2015). Despite success in simulating idealised city model with different packing density (Reda et al, 2017), these studies earned minimal attention mainly because they rely on numerical techniques. In this research, the use of experimental methods such as the wind tunnel, hotwire anemometry and pitot tube is desired to verify the theoretical results. The target of this research is to determine building-density effect on wind flow structure in a high-rise building city with height-to-width aspect ratio similar to KLCC. In the next 6-8 years, Kuala Lumpur will experience tremendous changes to its landscape. Few new skyscrapers are already in construction, one of them is the Exchange 106 as shown in Figure 1. Upon completion expected in 2018, at $492 \mathrm{~m}$, this 106-floor tower will be $40 \mathrm{~m}$ taller than the tallest building in Malaysia, KLCC, a position it holds for two decades. The position as the new tallest building in Malaysia however will be held only for approximately 
6 years as another skyscraper is being constructed. Upon completion expected in 2024, at $630 \mathrm{~m}$, the 118-storey Merdeka PNB 118 tower will dwarf both KLCC and Exchange 106. The race to build mega-structures is not expected to stop at least in the next decade, however it seems to outpace heat release study and initiatives within these skyscrapers. The results in this study are expected to give recommendations to the Kuala Lumpur city council regarding the infrastructure development of the city.

\section{METHODOLOGY \\ BUILDING MODEL}

The building-packing-density was obtained by image processing of the plan view of KLCC using the Image J 1.48 image processing software. While the average building dimensions were obtained by exporting every building in KLCC separately to a Stereolithography (STL) file which was later handled by Scilab ${ }^{\circledR}$ to get building length, width and height. The building length and width were defined as the dimensions in the streamwise and spanwise directions, respectively. The total number of buildings was 82 buildings. The average height-to-width of buildings and buildingpacking-density were 1.82 and $22 \%$, respectively.

It was decided to build a 1:1000 scale model with a building-packing-density of 2.0. Starting with block fabrication, one block consists of four sides acrylic sheets and one roof sheet. Side dimensions are $50 \mathrm{~mm} \times 100 \mathrm{~mm}$ with a sheet thickness of $5 \mathrm{~mm}$. While for roof sheets, square dimensions are $50 \mathrm{~mm} \times 50 \mathrm{~mm}$. The dimensions of the blocks proved to block less than $5 \%$ of the tunnel cross section. This was necessary to prevent the development of artificial acceleration past the building model (Franke et al. 2007). The acrylic was selected as the block material since it is of lightweight, easy to machine and has a minimal surface roughness. The sheets were joined using silicon glue to form blocks, Figure 2. The blocks were arranged in an array of $6 \times 6$ blocks. Three models with three spacings between the blocks were examined; 80, 50 and $35 \mathrm{~mm}$ which correspond to plane-area-ratios of 15,25 and $35 \%$ (1.3, 2 and 2.9 aspect ratios), respectively. Plan views of the tested models are shown in Figure 3.

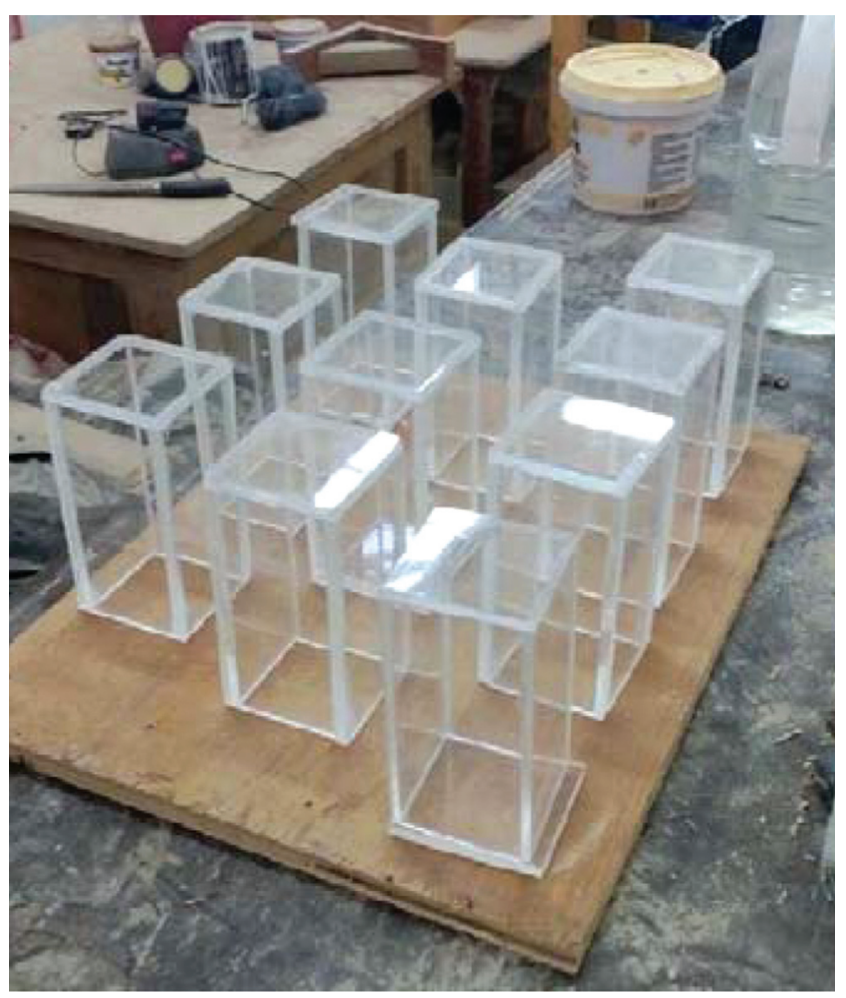

FIGURE 2.The acrylic sheet is stacked into blocks

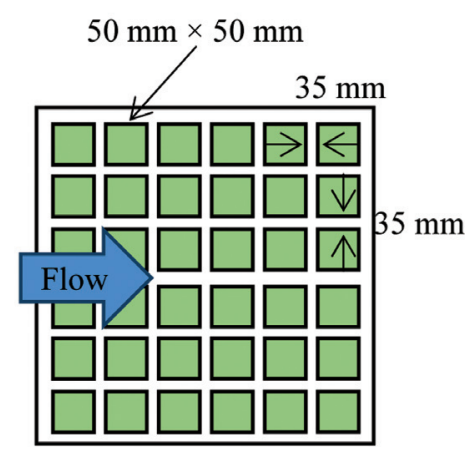

Model-I

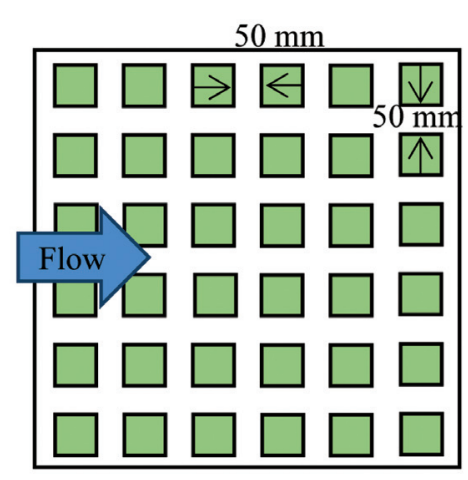

Model-II

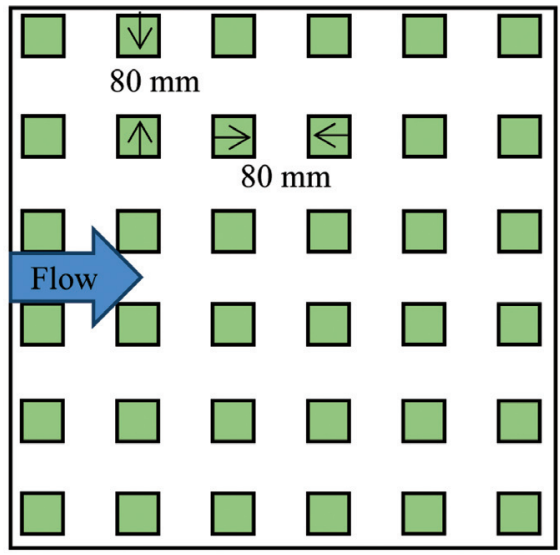

Model-III

FIGURE 3. The three models under consideration; representing three plane-area-ratios: 35,25 and $15 \%$ respectively 
FLOW FACILITY - THE PANGKOR LOW SPEED WIND TUNNEL (LST)

The velocity profile and turbulence intensity measurements were performed in an open-circuit blow type, low-speed turbulent boundary layer wind tunnel at the Faculty of Engineering and Built Environment, Universiti Kebangsaan Malaysia (UKM), this wind tunnel frequently referred to as Pangkor-LST. This facility was previously used by Harun et al. 2015 and Harun et al. 2016 for fundamental turbulence and airfoil studies.

The geometry of the tunnel is shown in Figure 4. The important features of the tunnel are a settling chamber and two screens followed by a contraction with an area ratio of 2.4:1, which leads to the test section of area $1200 \times 500 \mathrm{~mm}$ and total length $3000 \mathrm{~mm}$. The traverse is newly built and had previously been tested and verified by previous work of Harun and coworkers. It is selected with a ball screw pitch of $1.6 \mathrm{~mm}$ coupled with two Vecta, PK266, stepper motors ensuring a traversing resolution well below $0.1 \mathrm{~mm}$ in the spanwise and vertical directions. The motors are driven by Velmex model VXM-3 controllers sequenced automatically with the data acquisition system.

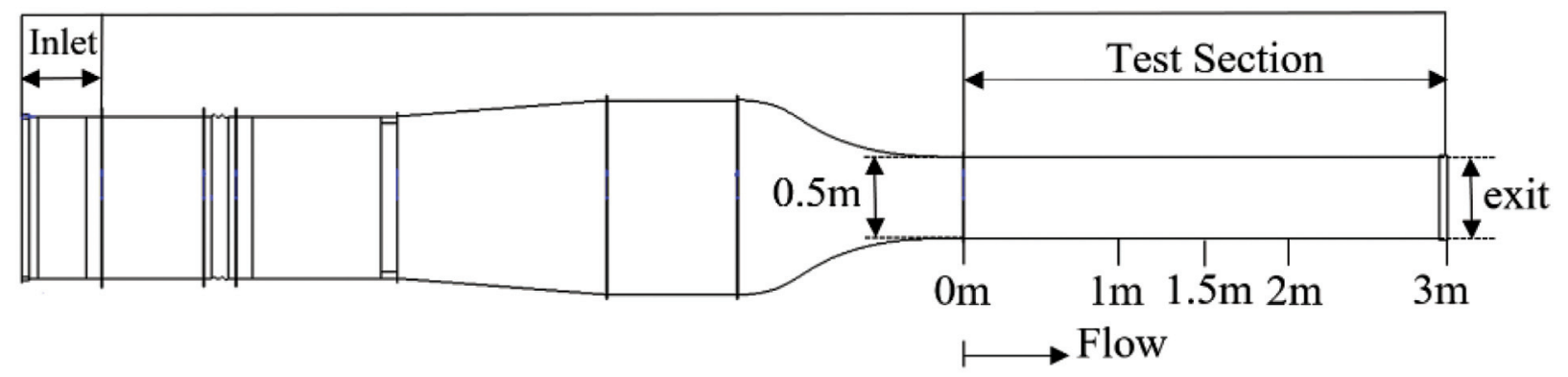

FIGURE 4. Illustration of Pangkor-LST wind tunnel geometry (Side view)

\section{DATA MEASUREMENTS}

The instrument used to take the measurements is the hotwire anemometry. There are four types of hotwire anemometry namely mini wire type, gold-plated type, fiber film type and fiber sensor. The wires implemented are of 5 micrometerdiameter and 1.2 millimeter-length. The bigger diameter platinum core here is needed to simplify experiment (in comparison with turbulence studies). This wire is soldered between two fine needles. The preset sampling frequency was $5 \mathrm{kHz}$ and sample time 60 seconds. These were required to capture accurate turbulence statistics. The sensitivity of the average velocity to the averaging time is illustrated in Figure 5, where, $U_{t}$ is the average velocity over the period $t$ and $U_{T}$ is the average velocity over 60 seconds. As shown, the average value changes by less than $\pm 0.2 \%$ along 180 seconds of sampling. The hotwire anemometer (which reads electric voltage) was calibrated with a pitot tube to convert the voltage reading into velocity in $\mathrm{m} / \mathrm{s}$.

The three models were subjected to a boundary layer flow of freestream velocity of $5 \mathrm{~m} / \mathrm{s}$, as shown in Figure 6. The velocity measurements were taken along the vertical axes passing through five equally-spaced positions, Figure 7 , behind a building in the middle of the array (fourth column from upstream, fourth row).

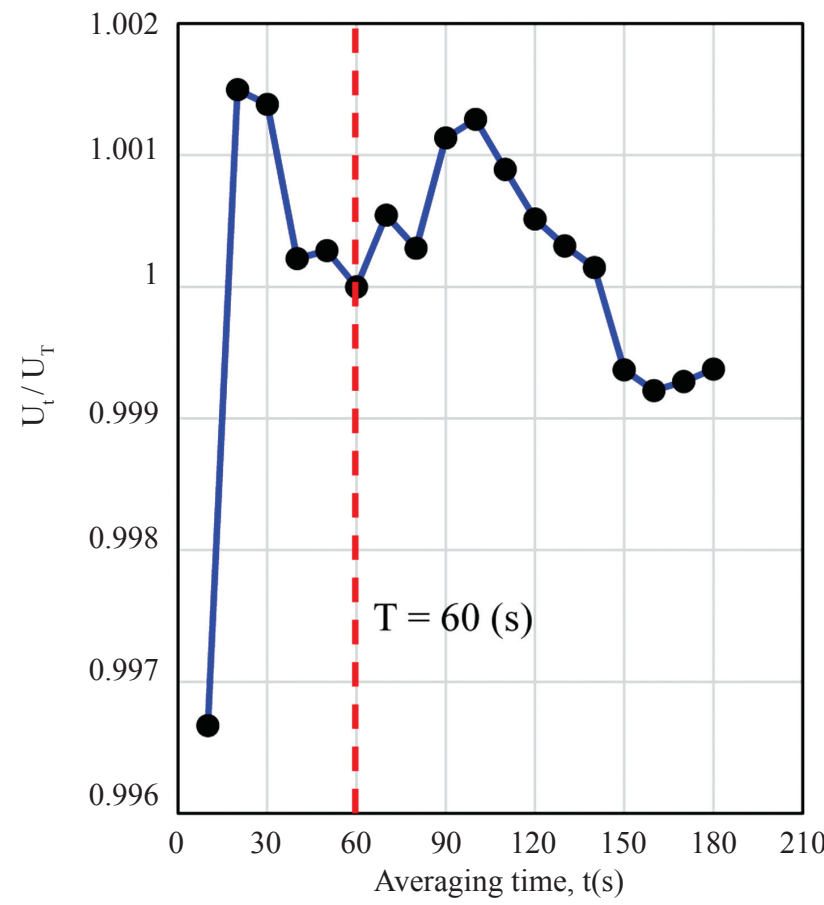

FIGURE 5. Effect of the averaging period on the calculated average velocity 


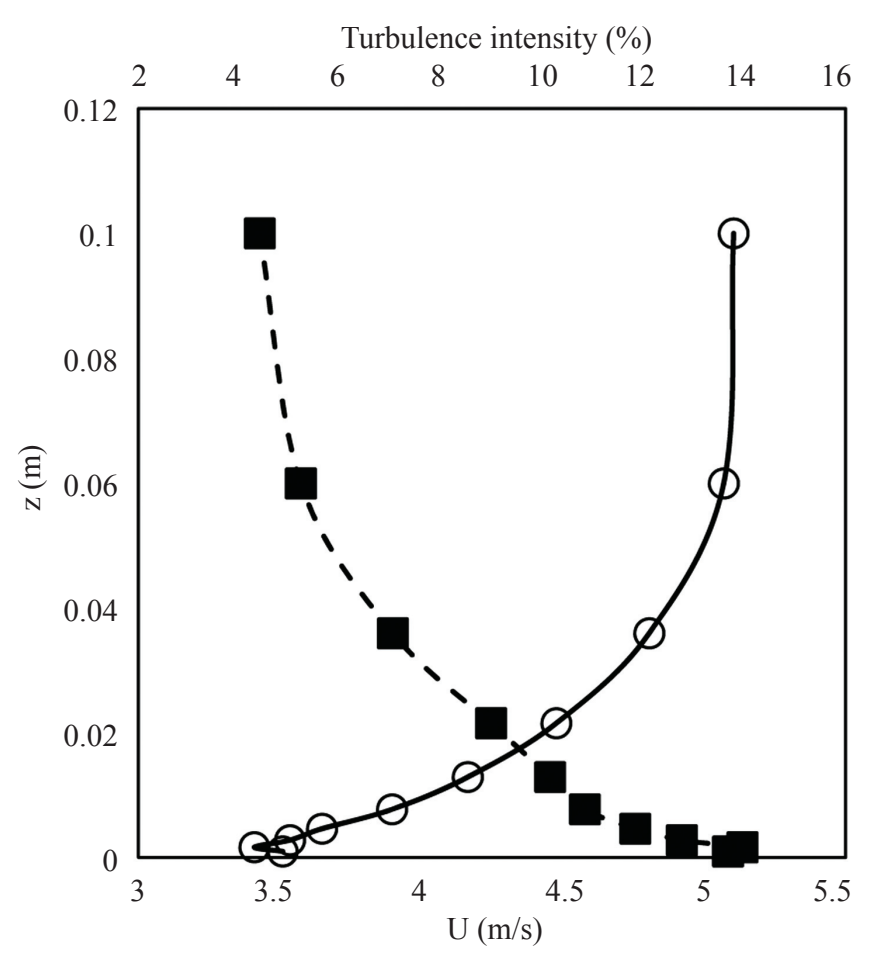

FIGURE 6. Velocity and turbulence intensity for the free flow boundary layer. $\circ$ : Velocity and $\mathbf{m}$ : turbulence intensity

\section{RESULT AND DISCUSSIONS}

Figure 8 shows the velocity profile and turbulence intensity through Model-II. As can be seen, the flow structure can be divided into two zones, namely, the "behind-building zone" (P1 and P2) and the "free zone" (P4 and P5). In each zone, the flow structure is coherent and exhibits semi-uniform velocity and turbulence intensity profiles. The free zone generally shows thrice the velocity in the behind-building zone and half its turbulence intensity. The edge between the two zones (P3) shows a depression in velocity and hump in turbulence intensity between $\mathrm{z} / \mathrm{H}=0.2-0.6$ because of

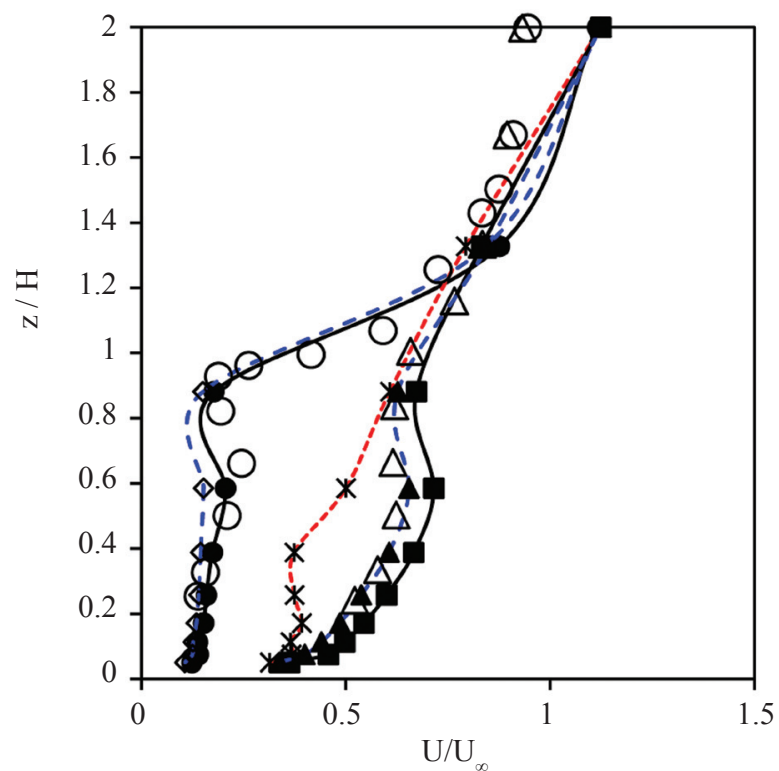

(a)

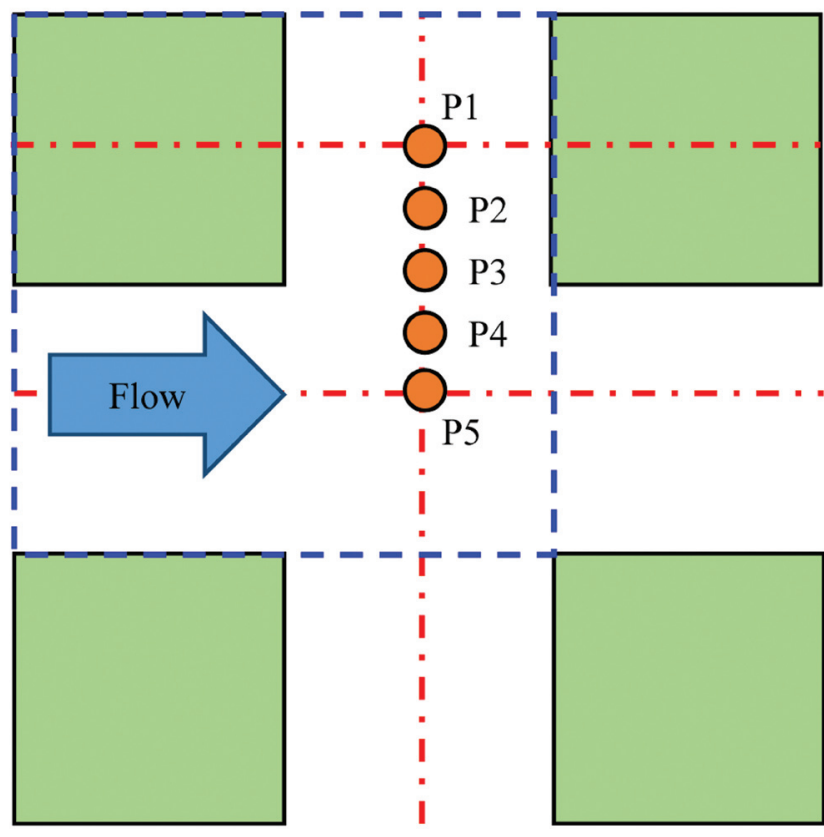

FIGURE 7. Plan view of the model illustrating the measurement axes

the formation of vortical structures due to flow separation. Another depression in velocity and hump in turbulence intensity can be noticed in the behind-building zone at $\mathrm{z} / \mathrm{H} \sim 1$ due to the vortical structures near the building roof. This coincides with the findings of Hang et al. (2011), among many others, who pointed out the development of two vortices in the behind-building region; the first is near the roof and the second near the ground. The profiles of velocity and turbulence intensity collapse at heights above $\mathrm{z} / \mathrm{H}=1.2$. Figure 7 (a) displays that the current velocity data at P1 and P5 largely agree with the measurements of Hang et al. (2011) at P1 and P5.

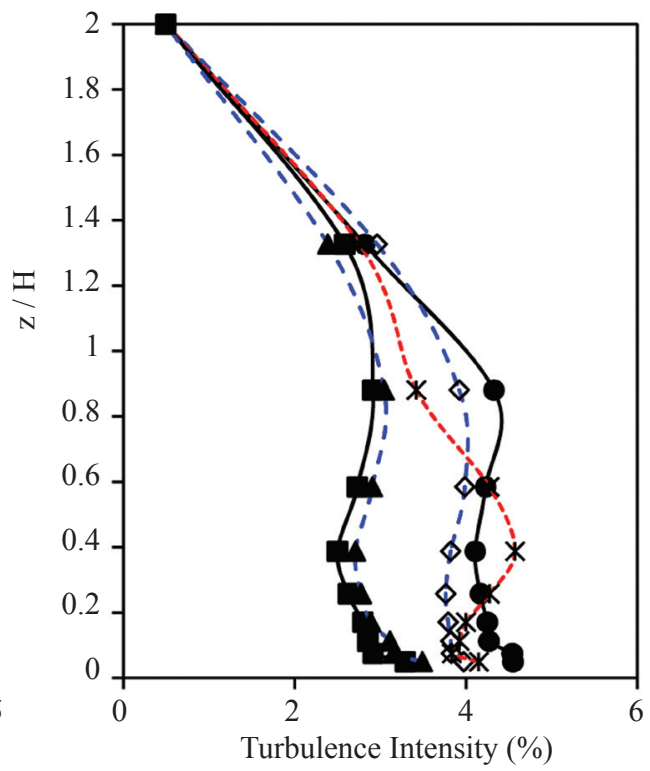

(b)

FIGURE 8. Velocity and turbulence of the wind flow through Model II. (a) Velocity and (b) turbulence intensity. $\bullet:$ P1, $\diamond: \mathrm{P} 2$ *: P3, $\mathbf{m}: \mathrm{P} 4$, and $\boldsymbol{\Lambda}$ : P5. ○: Hang et al. (2011) P1, $\square$ : Hang et al. (2011) 
Figure 9 compares the velocity and the turbulence intensity profiles at points P1 and P5 for the three models. Model-I, due to its high building density, shows the lowest velocity in the behind-building zone and the lowest turbulence intensities ever. Models II and III, display high and comparable values for both velocity and turbulence intensity. The hump that can be seen in the turbulence intensity profiles at P1 for both Models II and III disappears in Model I, indicating the suppression of the roof vortices. A depression in velocity and bulge in intensity can be noticed in the profiles of Model III between $\mathrm{z} / \mathrm{H}=0.4$ and 0.8 . The results speculate a weak performance for the high building density model regarding heat dissipation and pollutant dispersion. This confirms the finding by Lotfy et al (2017) that the best plane-area-ratio falls within 15-25\%. Thus building planner for KLCC should be aware of this safe plane-area-ratio.

The number of buildings implemented in this research $(6 \times 6)$ is fewer than the previous research where the flow passes over double the number of rows. The coincidence of the present results with Hang et al. (2011), although the limited number of buildings utilized, demonstrates the minority of the effect of the external flow structure on the velocity and turbulence profiles within the interior parts of the city. It also indicates that a reasonable accuracy can be achieved by simulating the flow within fewer number of buildings. More research is needed to reach a trade-off between the number of buildings and the fidelity of the results.

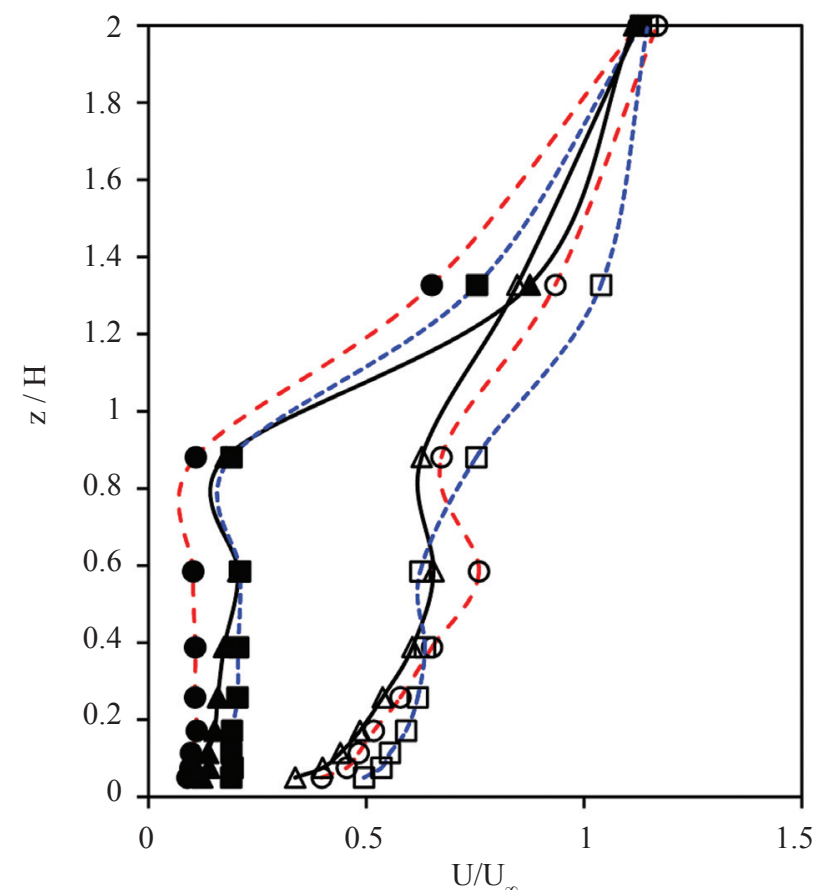

(a)

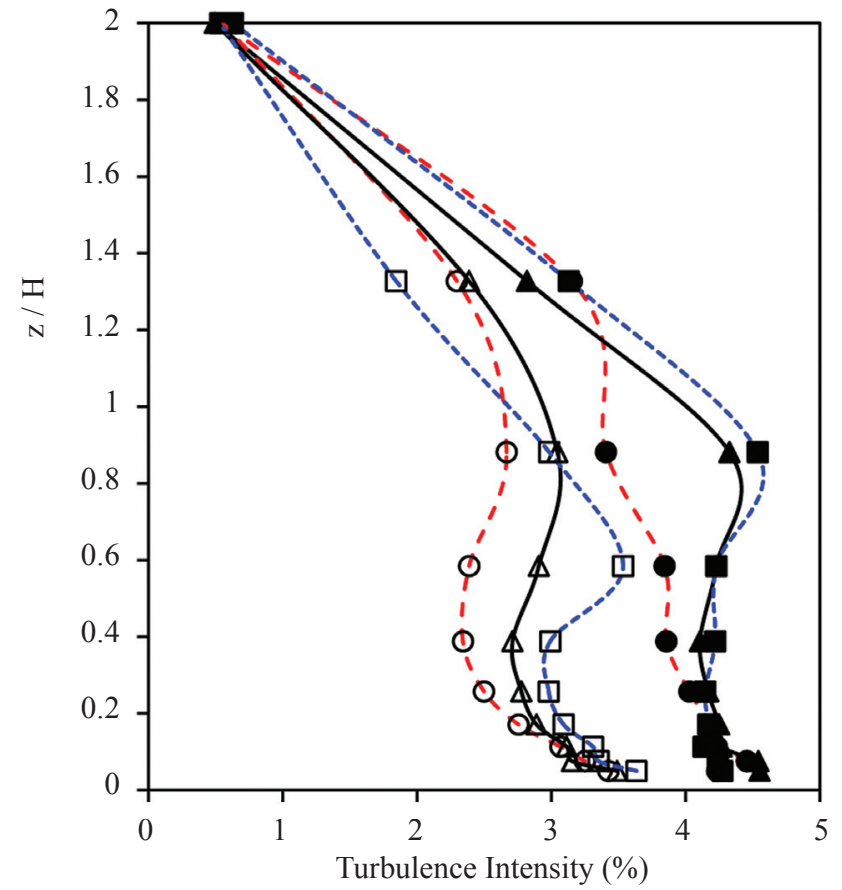

(b)

FIGURE 9. Comparing the velocity and turbulence intensity profiles of the three models at points P1 and P5. (a) Velocity and (b) turbulence intensity. $\bullet$ : Model-I, $\boldsymbol{\Lambda}$ : Model-II, and $\mathbf{m}$ : Model-III. The filled symbols correspond to point P1 and the open symbols correspond to $\mathrm{P} 5$

\section{CONCLUSION}

The present research is an experimental investigation of the effect of plan area ratio on the flow structure and turbulence intensity in a high-rise building area. Three models of different plan-area-ratios $(15,25$, and $35 \%)$ were tested in wind tunnel under the same inlet condition. The velocity profile was measured at five equally-spaced points downstream a building close to the array center. The results divide the flow structure into two zones; the behind-building zone and the free zone. The former is featured with lower velocity flow and higher turbulence intensity. Two vortical structures can be recognized near the building roof and near the ground. The high building-density model (35\%) suppresses the vortical structure in the behind-building zone and hence has a low heat dissipation capacity, which can intensify the UHI effect. The town planners in Kuala Lumpur especially in KLCC and Tun Razak Exchange (TRX) are suggested to keep the buildingdensity-ratio around $25 \%$.

\section{ACKNOWLEDGEMENTS}

We would like to express our gratitude for the financial supports provided by UKM fundamental research grant FRGS/1/2016/TK03/UKM/02/1. 
REFERENCES

Andersen, M. \& Skjoett-Larsen, T. 2009. Corporate social responsibility in global supply chains. International Journal of Life Cycle Assessment 14(2): 75-86.

Bailey, S. C. C., Hultmark, M., Smits, A. \& Schultz, M. P. 2008. Azimuthal structure of turbulence in high Reynolds number pipe flow. J. Fluid Mech. 615: 121-138.

Balachandar, S. \& Eaton, J. K. 2010. Turbulent dispersed multiphase flow, Annual Review of Fluid Mech. 42: 111-133.

Castro, I.P., Cheng, H. \& Reynolds, R. 2006. Turbulence over urban-type roughness: deductions from wind-tunnel measurements. Boundary-Layer Meteorology 118(1): 109-131.

Colin, M. 2013. Measuring the air speed created in a wind tunnel, Pamona College.

Flores, F., Garreaud, R. \& Mu noz, R. C. 2013. CFD simulations of turbulent buoyant atmospheric flows over complex geometry: Solver development in OpenFOAM. Computers \& Fluids 82: 1-13.

Gousseau, P., Blocken, B., Stathopoulos, T. \& Van Heijst, G.J.F. 2011. CFD simulation of near-field pollutant dispersion on a high-resolution grid: a case study by LES and RANS for a building group in downtown Montreal. Atmospheric Environment 45(2): 428-438.

Hang, J.\& Li, Y. 2010. Ventilation strategy and air change rates in idealized high-rise compact urban areas. Building and Environment 45(12): 2754-2767.

Hang, J., Li, Y. \& Sandberg, M. 2011. Experimental and numerical studies of flows through and within high-rise building arrays and their link to ventilation strategy. Journal of Wind Engineering and Industrial Aerodynamics 99(10): 1036-1055.

Hang, J., Li, Y., Sandberg, M., Buccolieri, R. \& Di Sabatino, S. 2012. The influence of building height variability on pollutant dispersion and pedestrian ventilation in idealized high-rise urban areas. Building and Environment 56: 346-360.

Harun, Z., Abbas, A.A., Dheyaa, R.M. \& Ghazali, M.I. 2016. Ordered roughness effects on NACA 0026 airfoil. In IOP Conference Series: Materials Science and Engineering 52(1), No. 012005

Harun, Z. \& E. Reda. Large eddy simulation of the air flow through Kuala Lumpur City Center. 2015. Proceedings of the 1st Thermal and Fluids Engineering Summer Conference, TFESC-1.

Harun, Z., Wan Ghopa, W. A. , Abdullah, A., Ghazali, M. I., Abbas, A., Rasani, M. R., Zulkifli, R., Wan Mahmood, W. M. F, Abu Mansor M. R., Zainol Abidin, Z. \& Wan Mohtar, W. H. M. 2016. The development of a multipurpose wind tunnel. Jurnal Teknologi 10: 63-70.

Hutchins, N., Nickels, T. B., Marusic, I. \& Chong, M. S. 2009. Hot-wire spatial resolution issues in wall-bounded turbulence. J. Fluid Mech. 635: 103-136.
Jiang, D., Jiang, W., Liu, H. \& Sun, J. 2008. Systematic influence of different building spacing, height and layout on mean wind and turbulent characteristics within and over urban building arrays. Wind and Structures 11(4): 275-290.

Jones, M. B., Marusic, I. \& Perry, A. E. 2001. Evolution and structure of sink flow turbulent boundary layers. J. Fluid Mech. 428: 1-27.

Liu, C.H., Cheng, W.C., Leung, T.C. \& Leung, D.Y., 2011. On the mechanism of air pollutant re-entrainment in two-dimensional idealized street canyons. Atmospheric Environment 45(27): 4763-4769.

Lotfy, E. R., Wan Mahmood, W. M. F., Zulkifli, \& R., Harun Z. 2017. CFD Simulation of automotive pollutant dispersion in high-rise building urban environment under deeply stable atmospheric condition. In proceedings: International Conference on Recent Advances in Automotive Engineering \& Mobility Research.

Perry, A. E., Marusic, I. \& Jones, M. B. 2002. On the streamwise evolution of turbulent boundary layers in arbitrary pressure gradients. J. Fluid Mech. 461: 6191.

Pope, S. B. 2000. Turbulent Flows. Cambridge University Press.

Razak, A.A., Hagishima, A., Ikegaya, N. \& Tanimoto, J. 2013. Analysis of airflow over building arrays for assessment of urban wind environment. Building and Environment 59: $56-65$.

Razali, M.N.H.A., Zaki, S.A., Ali, M.S.M. \& Arai, N. 2016. A numerical analysis of wind flow within and above idealised modified terraced house canyon in Malaysia. Procedia Engineering 169: 289-296.

Reda, E., Zulkifli, R. \& Harun Z. 2017, Towards developing an idealised city model with realistic aerodynamic features, Journal of Mechanical Engineering and Sciences 11(4): 2979-2992.

Salim, S.M., Buccolieri, R., Chan, A. \& Di Sabatino, S. 2011. Numerical simulation of atmospheric pollutant dispersion in an urban street canyon: Comparison between RANS and LES. Journal of Wind Engineering and Industrial Aerodynamics 99(2): 103-113.

Schotland, R. M. 2013. The measurement of wind velocity by sonic mean. Journal of Meteorology 12(1955): 386390.

Zaki, S.A., Jaafar, A.Z., Faiz, A., Mohammad, M.S.M.A. \& Razak, A.A. 2016. Investigation of surface roughness impact on mean wind flow using RNG k- $\varepsilon$ model. Jurnal Teknologi 78(9): 21-28.

Zhou, B. \& Chow, F. K. 2012. Turbulence modelling for the stable atmospheric boundary layer and implications for wind energy. Flow Turbulence and Combustion 88 255-277. 
Farhana Najwa Azman, Eslam Reda Lotfy, Ashraf Amer Abbas, *Zambri Harun

Department of Mechanical and Materials Engineering Faculty of Engineering \& Built Environment,

Universiti Kebangsaan Malaysia, Malaysia

Eslam Reda Lotfy

Mechanical Engineering Department,

Alexandria University, 21544,

Alexandria, Egypt

*Corresponding author; email: zambri@ukm.edu.my

Received date : $23^{\text {rd }}$ August 2017

Accepted date : $22^{\text {nd }}$ January 2018

In Press date : $1^{\text {st }}$ April 2018

Published date : $30^{\text {th }}$ April 2018 